\title{
An Integrated DEA and PROMETHEE II Method for Complete Ranking: An Application in Life-Insurance Sector
}

Nor Faradilah Mahad, Nur Azlina Abd Aziz, Farah Azaliney Mohd Amin and Jamilah Mohd Mahyideen

To Link this Article: http://dx.doi.org/10.6007/IJARBSS/v11-i10/11123

DOI:10.6007/IJARBSS/v11-i10/11123

Received: 16 August 2021, Revised: 22 September 2021, Accepted: 09 October 2021

Published Online: 28 October 2021

In-Text Citation: (Mahad et al., 2021)

To Cite this Article: Mahad, N. F., Aziz, N. A. A., Amin, F. A. M., \& Mahyideen, J. M. (2021). An Integrated DEA and PROMETHEE II Method for Complete Ranking: An Application in Life-Insurance Sector. International Journal of Academic Research in Business and Social Sciences, 11(10), 982 - 992.

Copyright: (c) 2021 The Author(s)

Published by Human Resource Management Academic Research Society (www.hrmars.com)

This article is published under the Creative Commons Attribution (CC BY 4.0) license. Anyone may reproduce, distribute, translate and create derivative works of this article (for both commercial and non-commercial purposes), subject to full attribution to the original publication and authors. The full terms of this license may be seen

at: http://creativecommons.org/licences/by/4.0/legalcode

Vol. 11, No. 10, 2021, Pg. $982-992$

Full Terms \& Conditions of access and use can be found at http://hrmars.com/index.php/pages/detail/publication-ethics 


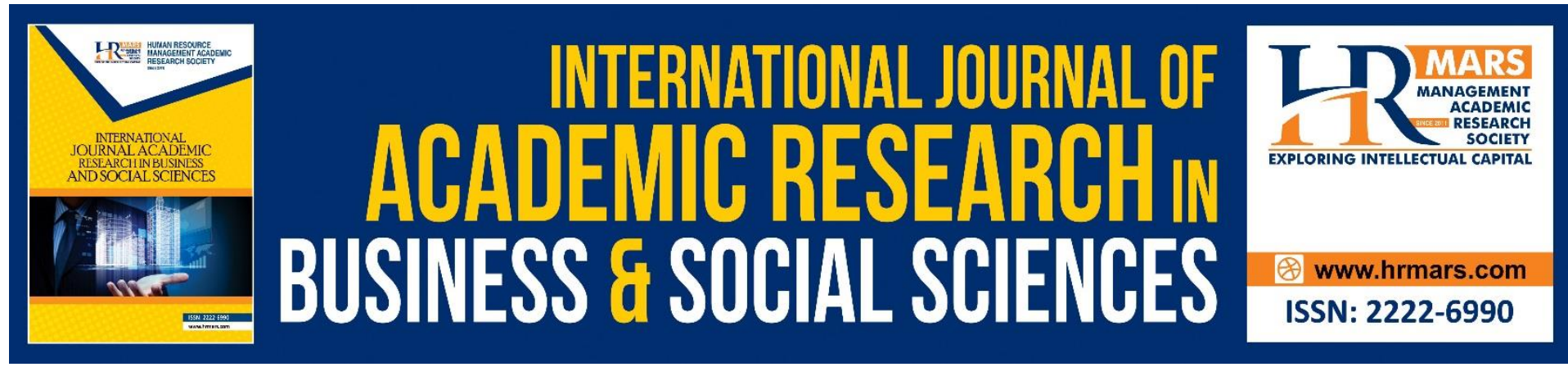

\title{
An Integrated DEA and PROMETHEE II Method for Complete Ranking: An Application in Life- Insurance Sector
}

\author{
Nor Faradilah Mahad ${ }^{1}$, Nur Azlina Abd Aziz ${ }^{1}$ Farah Azaliney \\ Mohd Amin ${ }^{1}$ and Jamilah Mohd Mahyideen ${ }^{2}$ \\ ${ }^{1}$ Faculty of Computer and Mathematical Sciences, Universiti Teknologi MARA (UiTM) \\ Cawangan Negeri Sembilan, Kampus Seremban, Persiaran Seremban Tiga/1, Seremban 3, \\ 70300, Seremban, Negeri Sembilan, Malaysia, ${ }^{2}$ Faculty of Business and Management \\ Universiti Teknologi MARA (UiTM) Cawangan Negeri Sembilan, Kampus Seremban, Persiaran \\ Seremban Tiga/1, Seremban 3, 70300, Seremban, Negeri Sembilan, Malaysia \\ Email: faradilah315@uitm.edu.my
}

\begin{abstract}
Globally, insurance and takaful companies play a crucial role in economic and financial development of a country. Malaysia's insurance sector has undergone substantial changes compared to two decades ago. Due to intense competition observed in Malaysian insurance industry, efficiency measurement and a complete efficiency ranking of insurance companies are very important for the decision makers so that necessary changes and improvement can be made. Data Envelopment Analysis (DEA) is a non-parametric method that has been acknowledged as an effective method to measure the efficiency of homogeneous decisionmaking units (DMUs). The main advantage of DEA is its ability to handle multiple inputs and outputs. However, standard DEA has poor discrimination power since it generates too many efficient units especially when the number of DMUs under study is insufficient in comparison to number of inputs and outputs. It cannot discriminate efficient units and therefore unable to give a complete ranking of DMUs. This study aimed to overcome the ranking problem found in standard DEA by integrating DEA and Preference Ranking Organization Method for Enrichment Evaluations (PROMETHEE) II. The hybrid method was applied to evaluate the efficiency and ranking of 22 life insurance and takaful companies in Malaysia from the period of 2017 to 2018. Input variables used in this study comprised of fees and commission, and management expenses. Meanwhile, output variables were net premium and generated investment income. The proposed method involved two stages. In the first stage, DEA was applied to obtain the efficient scores for the DMUs. In the second stage, PROMETHEE II was implemented to rank the efficient units. This hybrid method has successfully obtained full ranking of all the insurance companies under study. The inefficient companies can learn strategies and practices from efficient companies to enhance their services. It is recommended for future research to integrate DEA with other Multi Criteria Decision Making (MCDM) methods such as TOPSIS and VIKOR to fully rank the DMUs.
\end{abstract}

Keywords: DEA, PROMETHEE II, Efficiency, Ranking, Insurance Sector. 


\section{Introduction}

The Malaysian insurance industry has grown rapidly over the years and contributed significantly to Malaysia's total financial service sector. As reported by International Monetary Fund (IMF), insurance accounts about $6 \%$ of financial sector assets (IMF, 2014). Generally, insurance policies are categorised as life insurance and general insurance. Life insurance covers the life-risk of the person insure while general insurance non-life insurance covers other aspect and assets belong to a person such as health, education, car, house, and others.

Malaysian life insurance industry continues the growth momentum where the new business premium in 2019 surged by 14.9 per cent to RM11.8 billion compared to RM10.3 billion in 2018, indicating positive turnaround in the industry (LIAM, 2019). The main challenge facing the life insurance industry is that there is increasing competition from life insurance and takaful companies. Every life insurance and takaful company needs to function at its highest level on order to remain competitive in the market. The top management must know the efficiency level of their companies in utilizing inputs to produce outputs compared to its peers so that necessary changes and improvement can be made. They need to review the current business model and work out their business transformation strategies. Therefore, an effective and reliable efficiency measurement in insurance companies is necessary to ensure their continuous improvement.

Data Envelopment Analysis (DEA) has been recognised as an effective method that has been extensively applied to measure the efficiency of a set of homogeneous decision-making units (DMUs). Its strength lies in its competency to handle multiple inputs and outputs. However, one drawback in standard DEA is poor discrimination power as DEA generates many efficient units (Toloo, 2012; Bal et al., 2010). A complete ranking among all the DMUs is essential for decisiotyprsn makers (Toloo \& Nalchigar, 2009). However, DEA can classify DMUs as efficient and inefficient units. It cannot rank efficient DMUs because all efficient units have the same efficiency score of unity. Therefore, the full ranking among the efficient units is not possible in the standard DEA method.

Many researches were conducted to rank efficient units in DEA. Andersen and Petersen (1993), for example, introduced super-efficiency DEA approach. The method is omitting the DMU under assessment and will assess the remaining units. Wang et al., (2011) suggested a method based on regression analysis for finding a common set of weights to obtain a complete ranking for DMUs. Lotfi et al (2011) used Technique for order preference by similarity to ideal solution (TOPSIS) method to rank efficient units in DEA. Wang et al (2011) recommended a new method for ranking DMUs in DEA by imposing a suitable minimum weight restriction on all inputs and outputs.

Preference Ranking Organization Method for Enrichment Evaluations (PROMETHEE) is a criteria decision-making method that was introduced to attain partial ranking or complete ranking. This study applies the integration of DEA and PROMETHEE II methods to measure efficiency and provide a complete ranking for 13 life insurance and 9 takaful companies in Malaysia. PROMETHEE II is chosen over other versions of PROMETHEE due to its ability to achieve a complete ranking of alternatives from best to worst.

\section{Previous Studies on Efficiency and Ranking in Life Insurance Sector}

There have been a substantial number of studies done on measuring efficiency and ranking performance of insurance sectors. Abidin and Cabanda (2011) applied DEA to measure the efficiency of 23 Indonesn non-life insurance companies between 2005 and 2007. The findings suggest that there was a positive relationship between the size of the firm and its efficiency 
level. Zimková (2015) examined efficiency and ranking of 13 Slovak insurance companies in 2013 by employing DEA and super efficiency method. It was found that majority of the insurance companies under study were identified as efficient units. Jafari and Mousavi (2017) evaluated the performance and ranking of 9 insurance companies listed on the Iran capital market using DEA and statistical methods. The study used input-oriented BCC model. Sensitivity of each variable chosen was obtained by removing each variable in the efficiency evaluation and efficiency scores were computed and compared. Saad et al (2011) evaluated the efficiency and productivity of 9 life insurance firms in Malaysia and 2 life insurance companies in Brunei for the year 2000-2005 using DEA and Malmquist Index. The findings revealed that there is a positive relationship between total factor productivity and economic growth.

\section{Methodology}

In this section the methodology of DEA and PROMETHEE II are discussed.

\section{DEA}

The most basic DEA model known as CCR model was proposed by Charnes, Cooper and Rhodes in 1978 (Cooper et al., 2007). It was introduced to measure the relative efficiency of homogeneous DMUs with multiple inputs and outputs. A DEA model can be classified as input orientation or output orientation. The aim of input orientation is to minimize the inputs where output level is fixed. On the other hand, output orientation aims to maximize the output given the constant input level. Input orientation-CCR model is proposed in this study. The mathematical formulation for the model is given below:

Let $n$ be the number of DMUs where each $\operatorname{DMU}_{o}(o=1,2,3, \ldots, n)$ utilizes $m$ inputs to generate $s$ outputs.

$$
\begin{array}{ll}
\text { Maximize } & \theta_{o}=\sum_{r=1}^{s} u_{r} y_{r o} \\
\text { subject to } & \sum_{r=1}^{m} v_{i} x_{i o}=1, \\
& \sum_{\mathrm{r}=1}^{s} u_{r} y_{r j}-\sum_{i=1}^{m} v_{i} x_{i j} \leq 0 ; j=1,2, \ldots, n \\
& u_{r}, v_{i} \geq 0 .
\end{array}
$$

A $D M U_{o}$ is considered as relatively efficient if $\theta_{o}=1$, otherwise it is considered as inefficient unit.

In DEA, selecting the appropriate input and output factors is very crucial. This research used two inputs and two outputs to evaluate the efficiency of 22 life insurance and takaful companies in Malaysia from 2017 to 2018. The inputs chosen in this study are fees and commission; and management expenses that represented the amount paid by the company. These inputs were selected because both expenses provided a profound impact on the companies' performance, which were the two significant revenues for an insurance and a takaful company (Shieh et al., 2020).

13 life insurance companies and 9 takaful companies in Malaysia were chosen as DMUs in this study namely Allianz Life Insurance Malaysia Berhad, AIA Berhad, AXA Affin Life Insurance Berhad, Great Eastern Life Assurance (Malaysia Berhad), Manulife Insurance 
Berhad, MCIS Insurance Berhad, Prudential Assurance Malaysia Berhad, Sun Life Malaysia Assurance Berhad, Tokio Marine Life Insurance Malaysia Berhad, Gibraltar BSN Life Berhad, Zurich Life Insurance Malaysia Berhad, Hong Leong Assurance Berhad, AmMetLife Assurance Berhad, HSBC Amanah Takaful Berhad, Prudential BSN Takaful Berhad, Sun Life Malaysia Takaful Berhad, Zurich Takaful Malaysia Berhad, AIA Public Takaful Berhad, Etiqa Family Takaful Berhad, AmMetLife Takaful Berhad, Great Eastern Takaful and Hong Leong MSIG Takaful Berhad.

\section{PROMETHEE II}

PROMETHEE was first proposed by Jean Pierre Brans in 1984. This method belongs to the category of subordination relationships methods over classification, letting the ranking of alternatives from best to worst (Sanches et al., 2019). The method is based on mutual comparison of each alternative pair with respect to each of the criterion [15]. The PROMETHEE method is capable of handling both qualitative and quantitative data while suggesting different situations to managers on making the best decision (Sanches et al., 2019). Their main features are simplicity, clearness, and stability [16]. This method is very practical when groups of people are solving complex problems, especially those involving multiple criteria, concerning a lot of human perceptions and judgments, whose decisions have a long-term impact (Gavade, 2014). The other advantage of this method is, it is in the form of how each criterion is analysed and assessed, making it possible to determine the intensity of the assessments of each alternative with respect to each criterion (Sanches et al., 2019).

Different kinds of PROMETHEE methods ranged from PROMETHEE I, II, III, IV, V, VI, GDS, GAIA, TRI and Cluster can be used to solve different application problems (Brans et al., 1986; Polat et al., 2016; Wu et al., 2020). However, this research proposed the implementation of PROMETHEE II to obtain the complete ranking of the DMUs under study which failed to be determined by the application of classical DEA. Suppose there are $p$ efficient units out of 22 life insurance and takaful companies with efficient score of 1 , PROMETHEE II method is then implemented to fully rank the efficient units. The significant superiority of this method is that preference functions can be chosen based on numerous properties of attributes (Wu et al., 2019). PROMETHEE II is able to provide a complete ranking of a finite set of feasible alternatives based on pairwise comparisons of alternatives with respect to each criterion that may contain both tangible and intangible information, thus offering a comprehensive evaluation of performance (Kuang et al., 2015).

\section{PROMETHEE II Framework}

The PROMETHEE II method is applied to produce a full ranking of life insurance and takaful companies under study by pair wise comparison approach. There are 7 steps in the framework of PROMETHEE II (Sanches et al., 2019; Sen et al., 2015; Athawale \& Chakraborty, 2011) to produce the complete ranking of the companies (DMUs) as shown below:

Step 1: Create a decision matrix.

Step 2: The decision matrix is normalised by using

$$
\begin{aligned}
& R_{i j}=\frac{\left[y_{i j}-\min \left(y_{i j}\right)\right]}{\left[\max \left(y_{i j}\right)-\min \left(y_{i j}\right)\right]} \text { for } i=1,2,3, \ldots, m ; j=1,2,3, \ldots, n \text {. (benefit criteria) } \\
& R_{i j}=\frac{\left[\max \left(y_{i j}\right)-y_{i j}\right]}{\left[\max \left(y_{i j}\right)-\min \left(y_{i j}\right)\right]} \text { for } i=1,2,3, \ldots, m ; j=1,2,3, \ldots, n . \text { (cost criteria) }
\end{aligned}
$$


Step 3: Calculate the evaluative differences of $\mathrm{i}^{\text {th }}$ alternative with respect to another alternative, $d_{j}(p, q)$ using

$$
d_{j}(p, q)=g_{j}(p)-g_{j}(q)
$$

Step 4: Compute the preference function, $P_{j}(p, q)$ using

$$
\begin{aligned}
& P_{j}(p, q)=0 \quad \text { if } R_{p j} \leq R_{q j} \text { such that } D\left(M_{p}-M_{q}\right) \leq 0 \\
& P_{j}(p, q)=R_{p j}-R_{q j} \text { if } R_{p j}>R_{q j} \text { such that } D\left(M_{p}-M_{q}\right)>0
\end{aligned}
$$

Step 5: Compute the aggregated preference, $\pi(p, q)$ using

$$
\pi(p, q)=\frac{\sum_{j=1}^{n} w_{j} P_{j}(p, q)}{\sum_{j=1}^{n} w_{j}} \text { where } \sum_{j=1}^{n} w_{j}=1 .
$$

Given that $\sum_{j=1}^{n} w_{j}$ is the sum of the criteria weight.

Step 6: Measure the leaving and the entering outranking flow using

$$
\begin{aligned}
& \text { Leaving (positive) flow for } \mathrm{p}^{\text {th }} \text { alternative, } \varphi^{+}(p) \\
& =\frac{1}{m-1} \sum_{q=1}^{m} \pi(p, q) \text { where }(p \neq q) \\
& \text { Entering (negative) flow for } \mathrm{p}^{\text {th }} \text { alternative, } \varphi^{-}(p) \\
& =\frac{1}{m-1} \sum_{q=1}^{m} \pi(p, q) \text { where }(p \neq q)
\end{aligned}
$$

Step 7: Determine the net outranking flow for each alternative using

$$
\varphi(a)=\varphi^{+}(p)-\varphi^{-}(p)
$$

\section{Results and Discussion}

The efficiency scores for each life insurance and takaful companies derived from DEA model are summarized in Table 1. Note that, each of these marks has been rounded to 4 decimal points and is on a scale of 0 to 1 . A score of 1 refers to an efficient DMU, while a score of less than 1 indicates inefficient DMU. However, several companies obtain an efficiency score of 1 in 2017 and 2018. The findings reveal that 7 out of 22 DMUs are consistently considered as the best efficient life insurance observed in two consecutive years are AIA Berhad, Great Eastern Life Assurance (Malaysia Berhad), Manulife Insurance Berhad, Gibraltar BSN Life Berhad, Hong Leong Assurance Berhad, HSBC Amanah Takaful Berhad and Etiqa Family Takaful Berhad. Hence, this shows that DEA alone is not a good discriminator among DMUs since it is unable to give a distinctive ranking to fully evaluate the individual efficiency of the seven companies mentioned above.

Furthermore, Table 1 also shows an overview of efficiency scores for the other 15 life insurance and takaful companies in this study for 2017 and 2018. In 2017, 3 companies were considered as inefficient namely AmMetLife Takaful Berhad, Zurich Takaful Malaysia Berhad and Great Eastern Takaful each with scores of 0.4635, 0.4391 and 0.3556, respectively. While in 2018, the 3 inefficient companies are Prudential BSN Takaful Berhad (0.5066), Sun Life Malaysia Takaful Berhad (0.4520) and Great Eastern Takaful (0.4211). Overall, the scores represent an aspect that estimates output that is efficiency-oriented since this study applies 
a CCR model that has been mentioned previously. Therefore, this study proposes to integrate PROMETHEE II with DEA to get a complete ranking of the companies by discriminating the efficient DMUs.

Table 1: The Efficiency Scores of DEA

\begin{tabular}{|c|c|c|c|c|c|}
\hline \multirow{2}{*}{$\begin{array}{l}\text { Life Insurance and } \\
\text { Takaful Companies }\end{array}$} & \multicolumn{2}{|c|}{ Efficiency Score } & \multirow{2}{*}{$\begin{array}{ll}\text { Life Insurance and } \\
\text { Takaful Companies }\end{array}$} & \multicolumn{2}{|c|}{ Efficiency Score } \\
\hline & 2017 & 2018 & & 2017 & 2018 \\
\hline $\begin{array}{l}\text { Allianz Life Insurance } \\
\text { Malaysia Berhad }\end{array}$ & 0.7277 & 0.7692 & $\begin{array}{l}\text { Hong Leong Assurance } \\
\text { Berhad }\end{array}$ & 1 & 1 \\
\hline AIA Berhad & 1 & 1 & $\begin{array}{l}\text { AmMetLife Assurance } \\
\text { Berhad }\end{array}$ & 0.7440 & 0.6799 \\
\hline $\begin{array}{l}\text { AXA Affin Life Insurance } \\
\text { Berhad }\end{array}$ & 0.6880 & 0.6786 & $\begin{array}{l}\text { HSBC Amanah Takaful } \\
\text { Berhad }\end{array}$ & 1 & 1 \\
\hline $\begin{array}{l}\text { Great Eastern Life } \\
\text { Assurance (Malaysia } \\
\text { Berhad) }\end{array}$ & 1 & 1 & $\begin{array}{l}\text { Prudential BSN Takaful } \\
\text { Berhad }\end{array}$ & 0.4982 & 0.5066 \\
\hline $\begin{array}{l}\text { Manulife Insurance } \\
\text { Berhad }\end{array}$ & 1 & 1 & $\begin{array}{l}\text { Sun Life Malaysia } \\
\text { Takaful Berhad }\end{array}$ & 0.5277 & 0.4520 \\
\hline MCIS Insurance Berhad & 0.7214 & 0.6635 & $\begin{array}{l}\text { Zurich Takaful Malaysia } \\
\text { Berhad }\end{array}$ & 0.4391 & 0.5115 \\
\hline $\begin{array}{l}\text { Prudential Assurance } \\
\text { Malaysia Berhad }\end{array}$ & 0.7160 & 0.7099 & $\begin{array}{l}\text { AIA Public Takaful } \\
\text { Berhad }\end{array}$ & 0.5269 & 0.5464 \\
\hline $\begin{array}{l}\text { Sun Life Malaysia } \\
\text { Assurance Berhad }\end{array}$ & 0.6176 & 0.6173 & $\begin{array}{l}\text { Etiqa Family Takaful } \\
\text { Berhad }\end{array}$ & 1 & 1 \\
\hline Tokio Marine Life & & & AmMetLife & & \\
\hline $\begin{array}{l}\text { Insurance } \\
\text { Berhad }\end{array}$ & 0.8308 & 0.8367 & Berhad & 0.4635 & 0.5188 \\
\hline $\begin{array}{l}\text { Gibraltar } \\
\text { Berhad }\end{array}$ & 1 & 1 & Great Eastern Takaful & 0.3556 & 0.4211 \\
\hline $\begin{array}{l}\text { Zurich Life Insurance } \\
\text { Malaysia Berhad }\end{array}$ & 0.7383 & 0.7143 & $\begin{array}{l}\text { Hong Leong } \\
\text { Takaful Berhad }\end{array}$ & 0.5028 & 0.6562 \\
\hline
\end{tabular}

Table 2 below represents the ranking results via PROMETHEE II to deal with sorting problems among the 7 companies that have previously been selected as the best efficient units from DEA model. It is noticeable that Great Eastern Life Assurance (Malaysia Berhad) was the most efficient life insurance company since it had the highest net flow scores in 2017 and 2018 with 0.0645 and 0.0866 respectively. Indirectly, the results also show the ability of a company to remain competitive in the future. Recently, Great Eastern maintains a strong position as a leader in Asia's insurance industry with more than 1.2 million Malaysians covered. It has also been recognised upon winning several top awards such as Gold in the Reader's Digest 2020 Trusted Brands Awards in the Life Insurance and Health Insurance (Ibanding, 2020) 
Table 2: The Net Flow Scores of PROMETHEE II and Rank of 22 Companies

\begin{tabular}{|c|c|c|c|c|c|}
\hline \multirow[b]{2}{*}{$\begin{array}{l}\text { Life Insurance and } \\
\text { Takaful Companies }\end{array}$} & \multicolumn{2}{|l|}{2017} & \multirow[b]{2}{*}{$\begin{array}{l}\text { Life Insurance and } \\
\text { Takaful Companies }\end{array}$} & \multicolumn{2}{|l|}{2018} \\
\hline & $\begin{array}{l}\text { Net } \\
\text { Outrankin } \\
\text { g Flow } \\
\text { Score } \\
\end{array}$ & $\begin{array}{l}\text { Ran } \\
k\end{array}$ & & $\begin{array}{l}\text { Net } \\
\text { Outrankin } \\
\text { g Flow } \\
\text { Score } \\
\end{array}$ & $\begin{array}{l}\text { Ran } \\
\mathbf{k}\end{array}$ \\
\hline Eastern & & & Eastern Life & & \\
\hline $\begin{array}{l}\text { Assurance } \quad \text { (Malaysia } \\
\text { Berhad) }\end{array}$ & 0.0645 & 1 & $\begin{array}{l}\text { Assurance (Malaysia } \\
\text { Berhad) }\end{array}$ & 0.0866 & 1 \\
\hline $\begin{array}{l}\text { Etiqa Family Takaful } \\
\text { Berhad }\end{array}$ & 0.0079 & 2 & $\begin{array}{l}\text { Etiqa Family Takaful } \\
\text { Berhad }\end{array}$ & 0.0031 & 2 \\
\hline $\begin{array}{l}\text { HSBC Amanah Takaful } \\
\text { Berhad }\end{array}$ & -0.0012 & 3 & $\begin{array}{l}\text { HSBC Amanah Takaful } \\
\text { Berhad }\end{array}$ & -0.0066 & 3 \\
\hline $\begin{array}{l}\text { Manulife } \\
\text { Berhad }\end{array}$ & -0.0071 & 4 & $\begin{array}{l}\text { Manulife } \\
\text { Berhad }\end{array}$ & -0.0113 & 4 \\
\hline $\begin{array}{l}\text { Hong Leong Assurance } \\
\text { Berhad }\end{array}$ & -0.0080 & 5 & $\begin{array}{l}\text { Hong Leong Assurance } \\
\text { Berhad }\end{array}$ & -0.0143 & 5 \\
\hline AIA Berhad & -0.0258 & 6 & AIA Berhad & -0.0246 & 6 \\
\hline Gibraltar BSN Life Berhad & -0.0303 & 7 & Gibraltar BSN Life Berhad & -0.0329 & 7 \\
\hline Tokio Marine Life & & & Tokio Marine Life & & \\
\hline $\begin{array}{l}\text { Insurance Malaysia } \\
\text { Berhad }\end{array}$ & & 8 & $\begin{array}{l}\text { Insurance } \\
\text { Berhad }\end{array}$ & & 8 \\
\hline $\begin{array}{l}\text { AmMetLife Assurance } \\
\text { Berhad }\end{array}$ & & 9 & $\begin{array}{l}\text { Allianz Life Insurance } \\
\text { Malaysia Berhad }\end{array}$ & & 9 \\
\hline $\begin{array}{l}\text { Zurich Life Insurance } \\
\text { Malaysia Berhad }\end{array}$ & & 10 & $\begin{array}{l}\text { Zurich Life Insurance } \\
\text { Malaysia Berhad }\end{array}$ & & 10 \\
\hline $\begin{array}{l}\text { Allianz Life Insurance } \\
\text { Malaysia Berhad }\end{array}$ & & 11 & $\begin{array}{l}\text { Prudential Assurance } \\
\text { Malaysia Berhad }\end{array}$ & & 11 \\
\hline MCIS Insurance Berhad & & 12 & $\begin{array}{l}\text { AmMetLife Assurance } \\
\text { Berhad }\end{array}$ & & 12 \\
\hline $\begin{array}{l}\text { Prudential Assurance } \\
\text { Malaysia Berhad }\end{array}$ & & 13 & $\begin{array}{l}\text { AXA Affin Life Insurance } \\
\text { Berhad }\end{array}$ & & 13 \\
\hline $\begin{array}{l}\text { AXA Affin Life Insurance } \\
\text { Berhad }\end{array}$ & & 14 & MCIS Insurance Berhad & & 14 \\
\hline $\begin{array}{l}\text { Sun Life Malaysia } \\
\text { Assurance Berhad }\end{array}$ & & 15 & $\begin{array}{l}\text { Hong Leong MSIG Takaful } \\
\text { Berhad }\end{array}$ & & 15 \\
\hline $\begin{array}{l}\text { Sun Life Malaysia Takaful } \\
\text { Berhad }\end{array}$ & & 16 & $\begin{array}{l}\text { Sun Life Malaysia } \\
\text { Assurance Berhad }\end{array}$ & & 16 \\
\hline AIA Public Takaful Berhad & & 17 & AIA Public Takaful Berhad & & 17 \\
\hline $\begin{array}{l}\text { Hong Leong MSIG Takaful } \\
\text { Berhad }\end{array}$ & & 18 & $\begin{array}{l}\text { AmMetLife } \\
\text { Berhad }\end{array}$ & & 18 \\
\hline $\begin{array}{l}\text { Prudential BSN Takaful } \\
\text { Berhad }\end{array}$ & & 19 & $\begin{array}{l}\text { Zurich Takaful Malaysia } \\
\text { Berhad }\end{array}$ & & 19 \\
\hline $\begin{array}{l}\text { AmMetLife } \\
\text { Berhad }\end{array}$ & & 20 & $\begin{array}{l}\text { Prudential BSN Takaful } \\
\text { Berhad }\end{array}$ & & 20 \\
\hline $\begin{array}{l}\text { Zurich Takaful Malaysia } \\
\text { Berhad }\end{array}$ & & 21 & $\begin{array}{l}\text { Sun Life Malaysia Takaful } \\
\text { Berhad }\end{array}$ & & 21 \\
\hline
\end{tabular}


Based on this observation, the ranking is also found to be consistent for all the 7 top life insurance and takaful companies during the observed period in this study. For two consecutive years, the Etiqa Family Takaful Berhad recorded the second most efficient company, followed by HSBC Amanah Takaful Berhad, Manulife Insurance Berhad, Hong Leong Assurance Berhad, AIA Berhad and finally, Gibraltar BSN Life Berhad. As reported, Great Eastern Life Assurance (Malaysia Berhad), Etiqa Family Takaful Berhad and AIA Berhad were also consistently on the top five in the index ranking in 2017 and 2018 for Malaysian insurance companies (BrandIndex, 2020). Hence, other companies in this industry should adopt these 7 top companies' strategies and good practices in utilizing their resources efficiently to produce optimal output. Finally, the findings reveal that by employing PROMETHEE II, the complete ranking of the 22 Malaysian life insurance and takaful companies has successfully been achieved. As a result, the discrimination power of standard DEA model is increased.

\section{Conclusion}

Poor discrimination power is a major issue in standard DEA as it often identifies too many DMUs as efficient units. Moreover, it cannot differentiate between efficient units and therefore fails to rank all DMUs. This study integrated DEA and PROMETHEE II methods to measure the efficiency and ranking of 22 life insurance and takaful companies in Malaysia. Efficiency and ranking results provided by this hybrid method could assist insurance and takaful top management and in providing directions to their companies. The inefficient companies could learn from their efficient peers identified by this hybrid model and plan strategies to improve efficiencies.

\section{References}

Abidin, Z., \& Cabanda, E. (2011). Efficiency of non-life insurance in Indonesia. Journal of Economics, Business, and Accountancy Ventura, 14(3), 197-202. https://doi.org/10.14414/jebav.v14i3.46

Andersen, P., \& Petersen, N. C. (1993). A Procedure for Ranking Efficient Units in Data Envelopment Analysis. Management Science, 39(10), 1261-1264. https://doi.org/10.1287/mnsc.39.10.1261

Athawale, V. M., \& Chakraborty, S. (2011). A comparative study on the ranking performance of some multi-criteria decision-making methods for industrial robot selection. International Journal of Industrial Engineering Computations, 2(4), 831-850. https://doi.org/10.5267/j.ijiec.2011.05.002

Bal, H., Örkcü, H. H., \& Çelebioğlu, S. (2010). Improving the discrimination power and weights dispersion in the data envelopment analysis. Computers and Operations Research, 37(1), 99-107. https://doi.org/10.1016/j.cor.2009.03.028

Brandlndex. (2020). 2019 Index Rankings: Malaysia Insurance.

Brans, J. P., Vincke, P., \& Mareschal, B. (1986). How to select and how to rank projects: The PROMETHEE method. European Journal of Operational Research, 24(2), 228-238.

Cooper, W. W., Seiford, L. M., \& Tone, K. (2007). Data envelopment analysis: A comprehensive text with models, applications, references and DEA-solver software: Second edition. In Data Envelopment Analysis: A Comprehensive Text with Models, Applications, References and DEA-Solver Software: Second Edition. https://doi.org/10.1007/978-0-387-45283-8 
Gavade, R. K. (2014). Multi-Criteria Decision Making : An overview of different selection problems and methods. International Journal of Computer Science and Information Technologies, 5(4), 5643-5646.

Ibanding. (2020). Top 5 Life Insurance in Malaysia.

Jafari, M., \& Mousavi, M. (2017). Performance Analysis and Rating of Insurance Companies Using DEA in Iran Capital Market. Advances in Mathematical Finance \& Applications, 2(3), 41-50.

Kuang, H., Kilgour, D. M., \& Hipel, K. W. (2015). Grey-based PROMETHEE II with application to evaluation of source water protection strategies. Information Sciences, 294, 376389. https://doi.org/10.1016/j.ins.2014.09.035

Lotfi, F. H., Fallahnejad, R., \& Navidi, N. (2011). Ranking efficient units in DEA by using TOPSIS method. Applied Mathematical Sciences, 5(17), 805-815.

Mahad, N. F., Aziz, N. A. A., Amin, F. A. M., \& Mahyideen, J. M. (2021). An Integrated DEA and PROMETHEE II Method for Complete Ranking: An Application in Life-Insurance Sector. International Journal of Academic Research in Business and Social Sciences, 11(10), $963-972$.

Polat, G., Damci, A., Gurgun, A. P., \& Demirli, I. (2016). Urban Renewal Project Selection Using the Integration of AHP and PROMETHEE Approaches. Procedia Engineering, 164, 339-346. https://doi.org/10.1016/j.proeng.2016.11.628

Saad, N. M., Idris, N. E. H., \& Edzalina, N. (2011). Efficiency of life insurance Companies in Malaysia and Brunei : A comparative analysis. International Journal of Humanities and Social Science, 1(3), 111-122.

Sanches, A. M., Loures, de F. R. E., \& de Lima, E. P. (2019). Use of PROMETHEE method for decision making in bus fleet maintenance proposal of framework. Procedia Manufacturing, 39, 1913-1920. https://doi.org/10.1016/j.promfg.2020.01.241

Sen, D. K., Datta, S., Patel, S. K., \& Mahapatra, S. S. (2015). Multi-criteria decision making towards selection of industrial robot: Exploration of PROMETHEE II method. Benchmarking, 22(3), 465-487. https://doi.org/10.1108/BIJ-05-2014-0046

Shieh, H. S., Hu, J. L., \& Ang, Y. Z. (2020). Efficiency of Life Insurance Companies: An Empirical Study in Mainland China and Taiwan. SAGE Open, 10(1), 2158244020902060. https://doi.org/10.1177/2158244020902060

Toloo, M. (2012). Alternative solutions for classifying inputs and outputs in data envelopment analysis. Computers and Mathematics with Applications, 63(6), 11041110. https://doi.org/10.1016/j.camwa.2011.12.016

Toloo, M., \& Nalchigar, S. (2009). A new integrated DEA model for finding most BCC-efficient DMU. Applied Mathematical Modelling, 13(1), 597-604. https://doi.org/10.1016/j.apm.2008.02.001

Wang, Y. M., Luo, Y., \& Lan, Y. X. (2011). Common weights for fully ranking decision making units by regression analysis. Expert Systems with Applications, 38(8), 9122-9128. https://doi.org/10.1016/j.eswa.2011.01.004

Wu, Y., Zhang, B., Wu, C., Zhang, T., \& Liu, F. (2019). Optimal site selection for parabolic trough concentrating solar power plant using extended PROMETHEE method: A case in China. Renewable Energy, 143, 1910-1927. https://doi.org/10.1016/j.renene.2019.05.131

Wu, Y., Zhang, T., \& Yi, L. (2020). An Internal Type-2 Trapezoidal Fuzzy Sets-PROMETHEE-II based Investment Decision Framework of Compressed Air Energy Storage Project in China under the Perspective of Different Investors. Journal of Energy Storage, 
INTERNATIONAL JOURNAL OF ACADEMIC RESEARCH IN BUSINESS AND SOCIAL SCIENCES Vol. 11, No. 10, 2021, E-ISSN: $2222-6990$ @ 2021 HRMARS

30(January), 101548. https://doi.org/10.1016/j.est.2020.101548

Zimková, E. (2015). Technical efficiency and super-efficiency of the insurance sector in

Slovakia. Acta Universitatis Agriculturae et Silviculturae Mendelianae Brunensis, 63(6), 2205-2211. https://doi.org/10.11118/201563062205 